\title{
11 Eylül Sonrası Filmlerde Oryantalizm ve Karşı Oryantalizm Söylemleri: United 93 ve Yargesz İnfaz
}

Fikret GÜVEN'

\author{
$\ddot{O} \mathbf{z}$
}

\begin{abstract}
11 Eylül trajedisi, insan bilincinin iç çatlaklarına nüfuz ederek, Oryantalizm ve karşı- Oryantalizm söylemiyle yönetilen yeni bir Dünya Düzeninin başladığı bir olaydı. Saldırıların sembolik değeri ise tarihsel çatışmaları ve farklılıkları ispatlamak, psikolojik korkuları ve endişeleri uyandırmak ve bu günü ABD'ye yaşatan bir düşmana karşı kuvvet kullanımını haklı kılmak için güçlü bir araç haline getirmiştir. Saldırılara tepki olarak üretilen sanatsal eserler, saldırıların nasıl tasvir edileceği ile ilgili eleştirel tartışmanın da konusu olmuştur. Müslüman "Diğer" in temsili bu tartışmada ele alınan konulardan biridir. Terörist saldırıların ardından 11 Eylül sonrası filmler oryantalist siyasi söylemlere tepki göstererek, ana akım medyaya hakim olan basmakalıp söylemleri de reddetmiştir. Bazı film yapımcıları "Öteki"' in aynı basmakahıp imgesini yeniden üretirken bazıları bu kalıplaşmış söylemlere ve Oryantalizme meydan okumuştur. Bu çalışmada, Paul Greengrass'ın United 93 (2006) ve Gavin Hood'un Yargısız İnfaz (2007) adlı filmlerinde Müslüman "Diğer" in temsili analiz edilmektedir. Bu karşılaştırmada, film yönetmenleri arasındaki 11 Eylül saldırılarına ilişkin perspektifler sunulmuştur. Her iki filmdeki Oryantalizm' in süreklilikleri ve dönüşümleri araştırılmaktadır. Yaptığım analiz United 93'ün oryantalist söylemleri güçlendirdiğini ve sürdürdüğünü gösterirken, Yargısız İnfaz da daha dengeli bir yaklaşım sunarak aynı söylemi çürütmekte olduğunu göstermektedir.
\end{abstract}

Anahtar Kelimeler: 11 Eylül, Oryantalizm, United 93, yargısız infaz, İslam.

\section{Discourses of Orientalism and Counter - Orientalism in Post- September 11 Movies: United 93 and Rendition}

\begin{abstract}
The tragedy of September 11 was a world-changing event, as it penetrated the inner crevices of human consciousness and inaugurated a new World Order governed by a discourse of Orientalism and counter-Orientalism. The symbolical value of attacks became a powerful tool to prove historical conflicts between East and West conflicts, arouse psychological fears and anxieties, and justify the use of force against an enemy who had brought this unfortunate day on the United States. The artistic works produced in response to the attacks became the topic of critical debate about how to portray the attacks. The representation of the Muslim "Other" is one of the issues addressed in this debate. In the wake of the terrorist attacks, post-September 11 movies responded to the Orientalist discourses and stereotyping that dominated mainstream media. Some filmmakers reproduced the same stereotypical image of the "Other" while others challenged these stereotypes and Orientalist discourses. The present paper analyzes the representation of the Muslim "Other" in two movies: Paul Greengrass' United 93 (2006) and Gavin Hood's Rendition (2007). This juxtaposition is meant to present perspectives on the September 11 attacks among movie directors. I investigate continuities and transformations of Orientalism in both movies. My analysis indicates that United 93 reinforces and perpetuates orientalist discourses while Rendition refutes the same discourse by employing a
\end{abstract}

Öğrenci, Erciyes Üniversitesi, Edebiyat Fakültesi, İngiliz Dili ve Edebiyatı Bölümü, fikretguven@gmail.com [Makale kayıt tarihi: 18.2.2018-kabul tarihi: 14.4 .2018$]$ 
more balanced approach.

Key words: September 11, Orientalism, United 93, rendition, Islam.

\section{Introduction}

There have been several critical responses to works of fiction on September 11, mostly against the binary oppositions and Orientalist discourses. Such criticism revolves around the idea that artistic works on September 11 are inadequate in terms of their ability to respond to such a catastrophic event. The criticism also take works on September 11 to task for their inability to address issues on a global scale in terms of regional conflicts and their effective engagement with the 'Other' while analyzing reasons behind the terrorist activities. In his article "Open Doors, Closed Minds: American Prose Writing at a Time of Crisis" (2009), Richard Gray initiated the critical debate by analyzing the characteristics of literary and artistic works in response to crisis in American history to find patterns of disorientation after such events. He critiques the September 11 novel for its failed imaginative response to the crisis and wants it to engage the Other by following the pattern of immigrant works. Gray believes that September 11 works "domesticated" the crisis, because it primarily focused on American characters who suffer a personal trauma. Instead, he proposes alternative "imaginary structures" to bear witness to the trauma of September 11 and its consequences (Gray, 2009: 134). Gray argues that the existing September 11 works fail to engage the position of the "Other" in any depth due to their inability to "encounter with strangeness" (Gray, 2009: 73). He demands a shift in focus to "the bigger picture" instead of "familiar binary oppositions such as "us vs. them"” (Gray, 2009: 135) and calls for a "deterritorialisation" of artistic works on September 11.

In "A Failure of the Imagination: Diagnosing the Post- September 11 Novel,", Michael Rothberg considers Gray's model for the novel a centripetal one, which tries to bring the world to America, thus making it a universal nation. Rothberg believes in the possibility of a centrifugal model, and claims that some September 11 works have already begun that process. Rothberg argues that fiction can help us integrate subjective experience with global history and agrees with Gray, "September 11 works fail to move beyond the preliminary stages of trauma, and tends to focus on the domestic, even sentimental at times" (Rothberg, 2009: 152). While Gray suggests a turn towards immigrant works, Rothberg argues that this might actually cause a form of re-domestication (Rothberg, 2009: 155), since it would still be set within U.S. borders. Instead he suggests looking at September 11 from a universal perspective and overwhelmingly focuses on "international relations and extraterritorial citizenship" (Rothberg, 2009: 157). Retaining the U.S. as the cultural space in which the artistic works are set, as Gray suggests, could actually reproduce "American exceptionalism and ignore the context out of which the terror attacks emerged" (Rothberg, 2009: 158). As such he proposes to "pivot away from the homeland and seek out

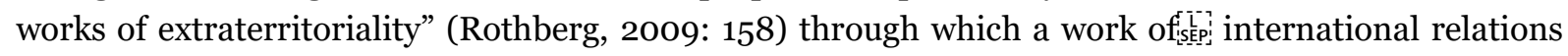
and extraterritorial citizenship could be realized. What Gray suggests is centripetal and is meant to bring the world to America, and make America a universal nation. Instead, Rothberg charts a centrifugal mapping, which pivots away from the homeland and searches a centrifugal literature of extraterritoriality. Gray and Rothberg believe that the September 11 fiction fails in its encounter with the cultural, and especially the Muslim, "Other" and significantly misses the opportunity of a constructive role in interpreting the events.

The stereotypical portrayal of Muslims in Western discourse has been a subject associated with the work of Edward Said. As a Palestinian activist and literary theorist, Edward Said formalized the binaries used 
to differentiate the East from the West with the theory of 'Orientalism'. Published in 1978, Orientalism describes a situation in which the West created a negative image of the East for self-motivation and definition. Said's argument is that the West represents the East on the basis of its own set of values, thus creating a distorted image of the East. He describes Orientalism as a "style of thought" based upon the acceptance of "the basic distinction between East and West as the starting point... concerning the Orient, its people, customs, 'mind,' destiny and so on" (Said, 1978: 2). Said regards the Orient that is presented through Orientalism as "a system of representations framed by a whole set of forces that brought the Orient into Western learning, Western consciousness, and later, Western empire” (Said, 1978: 203).

According to Said the cultural representations created and reinforced prejudices 'against non-Western' cultures, putting them in the rudimentary classification of the "Other." (Said, 1978: 73) The purpose of such a representation was to enable the West to define itself in cultural, political, social and psychological terms against its "contrasting image" (Said, 2009: 8). He claims "the Orient is eternal, uniform, and incapable of defining itself; therefore, it is assumed that a highly generalized and systematic vocabulary for describing the Orient from a Western standpoint is inevitable and even scientifically objective" (Said, 1978: 75). As such, Orientalism can be viewed as "a Western style for dominating, restructuring, and having authority over the Orient" (Said, 1978: 3). Using Orientalist discourses, the 'Other' is characterized as dictatorial, primitive, non-progressive, and violent in order to enable the projection of a progressive, democratic, and enlightened West. The West is active, creative, possessing agency and capable of generating knowledge, whereas the Orient is a passive object of Western study and a concoction of the Western imagination. The racist legacy of Orientalism, which regards difference as a threat that must be contained or destroyed is an ideologically charged abstraction and the West needs it in order to exert its hegemony and domination. Colonialist powers of the early twentieth century vigorously employed Orientalism in order to exploit distant parts of the world during their colonial quests. As the United States became a world power, it automatically adopted this tradition and during the 9os and after the Cold War, Said states "there was an effort in the West to depict Islam as the new evil after the dismemberment of Russia (Said, 1978: 355). This effort through the constant discourse of Orientalism met with heightened intensity after September 11.

Taking as my point of departure from the critical debate initiated by Richard Gray and Michael Rothberg, I use the discourses of Orientalism as the theoretical framework for a critical analysis of the movies United 93 and Rendition. The research investigates continuities and transformations of Orientalism in both movies. I argue that the Orientalist theories initiated by Said have transformed into more explicit and provocative levels due to the increasing nature of the conflict resulting from September 11.

\section{Orientalism in Post-September 11 World}

The attacks of September 11 inspired scholars to review Orientalism with renewed interest. Theories of Orientalism were formulated in relation to the responses to the attacks of September 11. As a constructed discourse, Orientalism is built on oppositions of the West: "us" versus the East "them". Since an identity cannot exist by itself or without negatives and opposites, Said claims that the Other has helped the West to be able to define itself as the "contrasting image, idea, personality, and experience which gained its strength and identity by setting itself off against the Orient as a sort of surrogate and even underground self." (Said, 1978: 2). The West is placed in a position of superiority, mastery, and control while the orient is portrayed as inferior, violent, corrupt, and uncivilized. The outcome of the discourse is that it creates a subordinate Other for control and self-actualization. Through the use of binaries, a superior, civilized, 
and rational self is established against an irrational and violent Other. By the creation of such power relationships, the powerful justifies colonizing and imperializing the less powerful. Said argues "An indispensable concept for any interpretation of cultural life in the industrial West is the hegemony employed in a "collective notion of identifying "us" European as against all "those" non-Europeans" (Said, 1978: 7). So, the superior has a justification to further colonialist objectives under the disguise of bringing civilization and democracy to the uncivilized. Said gives an example for this practice--Lord Macaulay's address to the British Parliament, which justifies the presence of the British Empire on Indian soil so that the natives could learn from them (Said, 1978: 152).

In Orientalism Said's main argument is that the West represents the East on the basis of its own interests. Said delineates that Orientalism is "a way of coming to terms with the Orient that is based on the Orient's special place in European Western experience" (Said, 1978: 1). The Orient is presented through Orientalism as "a system of representations framed by a whole set of forces that brought the Orient into Western learning, Western consciousness, and later, Western empire" (Said, 1978: 203). One of Said's points of criticism towards the Orientalist discourse is that the West sees the East as static, fixed, and incapable of change (Said, 1978: 106). Said argues that the East is not static and capable of change, but Orientalists conveniently ignore this fact because it does not fit their fixed definition of the East. Besides, the West dehumanizes the citizens of the Orient in order to control and exploit them. As Said argues, "a white middle-class Westerner believes it is his human prerogative not only to manage the nonwhite world but also to own it, just because by definition 'it' is not quite as human as 'we' are" (Said, 1978: 108). In the history of Orientalism, an important cultural situation is the "habit of deploying large generalizations" such as race and language, and underneath "these categories" is the "rigidly binomial position of 'ours' and 'theirs"' (Said, 1978: 227).

Fear of Islam is the most important aspect of Orientalism. Said believes that Islam has been met with fear and anxiety by the West since the Middle Ages, because the West always associated Islam with "terror, devastation, and the demonic hordes of hated barbarians"(Said, 1978: 89). Yet, the West also associates the East with "sexual promise, sensuality and unlimited desire" (Said, 1978: 189). The East, then, becomes both a threat and concoction of the Western imagination. In recent times, the depiction of Muslims has shifted "from a faintly outlined stereotype as a camel-riding nomad to an accepted caricature as the embodiment of incompetence and easy defeat" (Said, 1978: 285). The West distinguished between two kinds of Muslims. "There are good Muslims, the ones who do as they are told, and bad Muslims, who do not, and are therefore terrorists" (Said, 1978: 206). While the "good" Muslims submit to Western colonialism, those who oppose colonialism are labeled "bad" and even terrorists. Also, Muslim society is characterized as male-dominated and passive, in contrast to the democratic and enlightened West (Said, 1978: 311), thus reinforcing the opposition between "us" vs. "them."

Islam entered the contemporary Western news cycle initially because of connections to oil, Iraq, Iran, Afghanistan, and terrorism; thus, all of the major stories, and what the audiences in the West know about Islam and Muslims, are connected to control of the resource of oil, war, and terrorism. This kind of knowledge sets up minimal information of Islam, except for need, control, and fear, leading to Western reactions to Islam, as Edward Said argues, being largely Orientalist. In the post-September 11 World and after the U.S War on Terror in Afghanistan and Iraq, the interest in Orientalism was met with renewed interest. In the preface, written only months before his death, Said is disappointed that, in the U.S., Islam and Muslims have been even more subject to "demeaning generalization and triumphalist cliché" since September 11 (Said, 1978: xii). He explicitly blames the media, because it "recycles the same unverifiable fictions and vast generalizations so as to stir up 'America' against the foreign 
evil" (Said, 1978: xvi). He emphasizes his wish to employ Orientalism as "humanistic critique" to evoke more "understanding and intellectual exchange" among scholars instead of "polemical, thoughtstopping fury" that focuses on a collective identity (Said, 1978: xvii).

Orientalism had a major impact in the field of post-colonial studies. Said's theory altered the way scholars examine the relations between the East and the West, reconsidering them outside from the binary oppositions that characterized previous scholars' work. Consistent with Said's argument, Robert Nichols states, Orientalism is a "complex process of dominating the representation of non-Western peoples through the production of specific forms of knowledge about the non-West" (Nichols, 1980: 118). The West took it upon itself to represent the non-West as measured against Western values, leading to "distorted the images and forms of knowledge about the non-West" which "justified the ongoing physical-military colonization of lands and resources" in the non-West (Nichols, 2010: 118). Traditionally Western scholars had the upper hand in discussions of the East, yet Said's theory challenged this authority and the portrayal of the East by the West.

Even though several scholars accept Orientalism's significance and its influence in the post - September 11 world, Said's theory has its inconsistencies as well. Throughout Orientalism Said constantly defines and redefines the term, which leads to confusion. According to Clifford Orientalism is essentially "polemical," and "its analysis corrosive" (Clifford, 1980: 206), precisely because of the constant repetitive definition of Orientalism. Clifford claims that, Said "qualifies and designates Orientalism from a variety of distinct and not always compatible standpoints" (Clifford, 1980: 208). Besides its polemical and corrosive nature, the most glaring problem with Orientalism is its tendency to divide the world into two separate halves, thus falling back on the very binary oppositions it has come to criticize. As a response, Said states that even if binaries of "us" and "them" are removed, we cannot help to fall into equally other differentiations such as East - West, North - South, have - have not and so on. It would be counterproductive to assume that these binaries do not exist. (Said, Orientalism, p.335). Similarly, Bruce Robbins points out that Said "can be charged with keeping the unrepresented from representing themselves, substituting the West's own elite intellectual work for the voices of the oppressed" (Robbins, 1992: 50). This is an indication that Said is equally responsible for the same practice of which he accuses the West: having the authority to represent and speak on behalf of the "Other."

Because of the Muslim background of September 11 terrorists, there has been a revival of Orientalism in the post September 11 world. For the past two decades, Kumar remarks, discourses of Orientalism have revived which reinforces the distinction between "good" and "bad" Muslims (Kumar, 2012: 236). Consistent with this argument, the movies under discussion use orientalist and counter orientalist discourses. Maryam Khalid argues that, just as "Western constructs of Easterners as 'other' have been used to justify conquest and colonialism," after September 11 a new version of Orientalism appeared to legitimize America's War on Terror (Khalid, 2011: 15). Upon the attacks, hostility towards the Middle East increased, and the Muslims in general were held responsible for the terrorist. Khalid argues that the U.S. positioned itself as the leader of the "civilized world," taking upon itself the responsibility to liberate the Middle East of its oppressors (Khalid, 2011: 20).

The oppression of women is the most common charge against Islam by the Orientalist in the justification of War on Terror. The accusation of relegation of women to an inferior position in Muslim society actually stems from the Islamic practice of the veil. Leila Ahmad argues that the Western narrative has "always formed part of the quintessential otherness and inferiority of Islam" (Ahmad, 2012: 319). The stereotype is part of "a civilizational discourse among Western imperial nations, which have historically 
represented Islam as a backward religion" (Ahmad, 2012: 177), and the representation of female subjugation in Islam has become a common feature of Orientalist discourse. According to Leila Ahmad "... the thesis of the new colonial discourse of Islam centered on women... Islam was oppressive to women, that the veil ...was the comprehensive backwardness of Islamic society" (Ahmad, 2012: 152). Judith Butler also argues that the creation of the female, veiled "Other" who needs to be liberated from the male, cruel "Other" allowed the U.S. to present itself as a "morally and physically superior" nation (Butler, 2012: 28). Therefore, veiling or hijab has apparently been the most striking signal of divergence and inferiority of Muslim countries from the Western viewpoint. The fact that many women in Islamic countries are veiled was seen as an evidence of male oppression, from which women need to be saved.

After September 11, the most recognizable image of Muslims that emerged in Western mainstream media, apart from veiled women, was that of bearded male extremists. Because the media portrays growing a beard as a religious obligation in Islam to perpetuate a faulty syllogism that beards are mandatory in Islam, it has become an element of humor in the characterization of Muslims along with their strange habits and single-mindedness. For this stereotypical image of Muslim men, Grewal argues that the mainstream news media only portrayed the so-called "bad" Muslim in the precarious post September 11 atmosphere. The media gave them the characteristics of "fanatical, well-trained, dangerous and thus barbaric" Muslims (Grewal, 2003: 545). This is what created our image of Muslim terrorists. The media's creation of this "Other" enabled Americans to create their own identity and form solidarity with the victims and fundamentally separating themselves from the terrorists. Muslims are labeled as "bad," because this is the stereotype the mainstream media fed their audiences with. In regards to the framing used by media in their coverage of Muslims, Sharon Lauricella argues that there is a "deep-seated Orientalist treatment of Islam as "Other." After September 11, they argue a "NeoOrientalist discourse" emerged, setting news in a "terrorist frame" (Lauricella, 2011: 21). This "terrorist frame" has become the "master narrative," and intensified the post-September 11 Orientalist discourses (Lauricella, 2011: 21). The discourse characterized by the negative and stereotypical depiction of Muslims did not merely occur in the media, but emerged in post-September 11 movies as well. One of the works discussed in this paper, United 93, draws on Orientalist discourses whereas the movie Rendition tries to oppose prevailing Orientalist stereotypes and discourses.

\section{The Portrayal of the Muslims in United 93 and Rendition}

The September 11 terror attacks were arguably the most dramatic media spectacle in history. Attacking the heart of U.S. symbol of economic power--the World Trade Centers--and the symbol of U.S. military power-Pentagon--the terror spectacle took over live global media for days. According to Zizek the destruction of the towers was aestheticized both by the terrorists "who aimed to create a media event" and through "the style of the televised coverage, which had much in common with film and disaster movies." (Zizek, 2008: 11). The events of that horrendous day were broadcasted worldwide and reminded viewers all over the world of a scene from a disaster movie. Rickli states previous movies about America under attack had always positioned "good versus evil in a predetermined setting where the American side always wins." In almost all cases "the American under attack rises up and eventually defeats the perpetrator" (Rickli, 2009: 9). Since the actual attacks did not have U.S. victory, they "confronted the American public with a defective and thus unsettling reference to prototypical scenes of an important Hollywood genre" (Rickli, 2009:11). The movie-like events were shocking, but the absence of a happy ending caused a much bigger shock. Due to the gravity of the attacks and lack of element of U.S victory, Hollywood filmmakers were troubled by the question of how to deal with the subject. It took several years before movie industry produced movies based on September 11. The first major production, 
United 93, focused on the predicament of the American passengers and by employing an orientalist approach portrayed the Muslim terrorists as vicious "Others." Released a year later, Rendition was one of the first September 11 movies to take a critical position towards the U.S. belligerent foreign policy and the War on Terror.

Paul Greengrass's United 93 is a biographical drama thriller movie based on the historical hijacking of one of the four planes on September 11, 2001. It was one of the first movies Hollywood produced that dealt exclusively with the attacks. United Airlines 93 was on its way to San Francisco when hijacked by terrorists. This is the only hijacked plane that did not hit its initial target, presumably the White House in Washington, DC. The movie plot constantly shifts between the events on board of the plane and the flight control room on the ground. Even though United 93 is about the devastating attacks, it brings to the forefront the courage and heroism of the passengers and crew aboard the plane. The movie shows that America stands united and will survive, a positive message that might help the Americans to deal with the trauma caused by the attacks. Despite the horrendous nature of the attacks, the idea that the heroic passengers prevented the plane from hitting its target gave Americans the chance to feel that not everything was as bad as they thought, thus restoring some sense of peace. By focusing on the bravery of the passengers United 93 reinforces American "exceptionalism" and the idea that Americans are extraordinary and still superior. The underlying message of the movie is: even if the terrorists win in the short term, Americans will fight back and eventually win the fight against terrorism.

On the morning of the attacks, passengers and four terrorists board United Airlines 93. Ben Sliney, FAA National Operations Manager, is in a conference when it is reported that American Airlines Flight number 11 from Boston to Los Angeles has been hijacked. Minutes later the aircraft crashes into the North Towers of World Trade Center. Much to Sliney's horror, a second flight also has been hijacked and it is seen live on TV crashing into the South Tower. Sliney and his staff realize they are dealing with several hijackings. Meanwhile, on United 93, one of the terrorists assembles a fake bomb out of plastic. Then, al-Ghamdi makes the first move and grabs hold of a flight attendant at knifepoint. After a passenger is fatally stabbed and the "bomb" is revealed, causing panic among passengers, two terrorists force all the passengers to the back of the plane. Terrorists threaten the flight attendants and make their way into the cockpit. The pilots are killed and dragged from the cockpit. Jarrah turns the plane, intending to crash it into their target: the White House. Aboard United 93, the passengers become aware of the dead bodies, and learn from family members via air phone about the earlier attacks; they decide to take action and to organize a mutiny to take over the plane. After passengers arm themselves and make final phone calls to the loved ones, the group begins their counterattack, rushing down the aisle and overpowering all the terrorists. The passengers then breach the cockpit and al-Ghamdi orders Jarrah to crash the plane. Nonetheless, the passengers finally gain entrance. As the passengers and hijackers struggle for control, the plane plummets into a nosedive and goes upside down as the screen fades to black. Title cards reveal the plane crashed into a field, killing everyone on board.

United 93 claims to tell the story as it actually happened on board of the plane and in the flight control room, and thus attempts to blur the distinction between reality and fiction. However, the drama's tracing of the events as they occurred makes it impossible for the movie to move beyond the event itself and to address the issue in a wider global aspect. According to Slavoj Zizek, the realistic element of the movie engages the viewer, but also means that the movie is "restrained from taking a political stance and depicting the wider context of the events" (Zizek, 2006: 18). Zizek's suggestion that the movie lacks an important political and global engagement is consistent with Gray and Rothberg's critique of September 11 fiction. Because most viewers witnessed September 11 through television coverage, the subsequent 
creation of movies showing those same images blurs the boundaries between reality and fiction. The line between the actual events and the scripted movie may well cause viewers to incorporate the fictional images from the movie into their memory as if they were real, which causes the viewer to accept the depiction of the terrorists in the movie as absolute and accurate.

The movie's treatment of the terrorists is, in fact, ambiguous and prejudiced. The viewer is introduced to the terrorists at the very beginning, even before the movie takes the viewer to the airport. The scene begins with scenes of Muslim men praying, and talking in Arabic, and it looks as if they are preparing for a normal trip. People go to the airport, where a seemingly ordinary day begins. Planes are leaving, passengers are checking in, and routine situations in the flight control room are presented. French argues that "the function of the opening is to isolate the hijackers from their victims, but we are told nothing of their backgrounds" (French, 2006: 8). What's striking is that their prayers and conversations are not subtitled. It makes sense that they speak in Arabic, for the terrorists were Muslim-Arabs, but the non-Arab speaking viewer is left in the dark as to what is being said. Their religious rituals are not explained and the only recognizable phrase is "Allah-u Akbar." This treatment leads to the perpetuation of old stereotypes and Orientalist discourses. The terrorists are religious fanatics, for they all continually pray and call upon Allah, a practice that is associated with Islamic fundamentalism, and therefore reinforces and perpetuates the stereotypical link between Muslims and terrorism.

This alienation of the terrorists continues throughout the movie. Once the plane is airborne and the terrorists discuss among themselves when to take action, some of their lines are conveniently subtitled, however the subtitling is restricted to those parts of the script that are essential to perpetuate the stereotypical image of Muslim terrorists. Once they take control of the plane, their prayers and yelling at the passengers are not subtitled at all. According to Ford, this sets the hijackers in an "alien realm" (Ford, 2011: 48). The terrorists' motives are supposedly religious, but their "belief is without meaningful content, without application in the world inhabited by the rest of the passengers" (Ford, 2011: 45). Thus, the movie falls back on Orientalist stereotypes of Muslims being alien and strange. The accuracy of such knowledge is highly questionable, no background knowledge of the terrorists is presented.

The first thing that stands out in the movie is the tenseness and indecisiveness of the terrorists. Jarrah who eventually flies the plane and appears to be in charge of the rest is the most hesitant of all. On board of the plane, he gives the impression that he might want to abandon his original plan. When one of his fellow terrorists comes to his seat and asks, "why are we waiting", he says "it is not the right time". This suggests the Orientalist discourses that portray Muslims as ambivalent and "gnawing feeling of never fitting' in about most issues. As "an insider and outsider ... Muslims embody the postcolonial condition of a world citizen who has to come to terms with his own ambivalence and in-betweenness" (Elia, 2012, p. 59). However, the main reason of his hesitance seems to be that they do not have the situation under control, thus giving the passengers a chance to overpower the perpetrators. Yet, there is no actual evidence of hesitation among the perpetrators during the real event. The director's choice to depict the terrorist leader as hesitant is in sharp contrast with the heroism and determination of the passengers. Another example in the movie that contributes to the humanity of the terrorists takes place just before boarding. He makes a phone call to his girlfriend, which is subtitled: "I love you". This is a subtle moment where the "Other" is granted humanistic traits, yet this moment is very brief and is not elaborate and dramatic, causing the viewer to forget it almost instantly. Despite these scenes in which terrorist characters are portrayed as human, the focus of the movie remains on the heroic American passengers. The backgrounds of the passengers aboard of the plane are not developed individually or specifically, but there is still a distinction between the way the movie treats them and the terrorists. The hijacking 
unfolding aboard the plane is consistently presented from the passengers' perspective, which causes the viewer to identify with the passengers.

The ending of the movie is significant as the last scene merges reality with fiction. The passengers are dead in real life too and this blurs the distinction between fantasy and reality. At the very moment that the climax is about to take place, the screen fades to black. The viewer has been consumed by the story for two hours, and the effect of the ending is that the viewer identifies with the fallen victims, since the fact that passengers are dead in the real life too. Even though the terrorists show visible hesitation and the movie slightly attempts to humanize them, the terrorists are separated from the rest of the passengers, or, "we" are separated from "them." The movie suggests that there are no similarities between "them" and "us." As Michael Rothberg says, fiction is "an allegory of deterritorialized America" and that "echoes in many places earlier stories of American self-invention, but it resituates them in a fully globalized world" (Gray, 2009: 156). Such internationalization is possible in "hybrid, heterogeneous" spaces, as these spaces resist the discourse of "us-versus-them" on which the verbal currency of terrorism and counter-terrorism depends" (Gray, 2009: 70). The only Muslims shown in the movie might be capable of love and human doubt, yet their language, habits, and religion are fundamentally violent, which leads to a negative and threatening image of the Muslim "Other." Ford remarks that the hijackers narrative is "static and fixed" (Ford, 2011: 44), in contrast to that of the passengers. The terrorists remain same, static individuals; demonstrate an essential, unchanging Muslim character and mindset from the early days of Islam to the present day. This character and mindset arise from religious beliefs and shape all contemporary Muslims. The movie reinforces this process of repetitious fixity. Economic issues, local histories, political and social changes or the pressure of external forces on contemporary Islamic societies are all dismissed as irrelevant than the unchanging sway of monolithic and static categorization of Islam that held over its followers' minds and behavior. As a strategy in stereotyping, the same fixedness is recurrent in individual and collective lives. Muslims are indistinguishable mass with un-pliable fixed identities because they are what they are, and will never change. The individual stereotype only shows the collectivity stereotype. As a result, the viewers are likely also to accept the Orientalist image of the terrorists, and possibly by extension all Muslims, as static and unchanged "Others."

Directed by Gavin Hood, Rendition was released in 2007, just one year after United 93. The movie is an abduction thriller movie that tries to shed light on the political aftermath of the attacks and the controversial practice of extraordinary rendition. The War on Terror and the curtailment of civil liberties by the Patriot Act are heavily criticized as well. The setting of the movie alternates between two countries, the U.S. and an un-identified Muslim country, indicating that this movie includes a universal perspective on the effects of September 11. Two storylines run simultaneously in the movie; one plotline begins with CIA agent Freeman and the bombing which leads to El-Ibrahimi's kidnapping. The second plotline displays two Muslim teenagers falling in love. Fawal's daughter is in love with a man who turns out to be the suicide bomber that carried out the terrorist attack.

CIA analyst Douglas Freeman is a newly arrived CIA agent. He is briefed about a suicide attack that has left 19 people dead. The target was a high-ranking police officer, Abbas Fawal, who acts as a liaison for the U.S. Abbas carries out interrogations and torture to extract intelligence for the benefit of U.S government. Anwar El-Ibrahimi, a chemical engineer who lives in Chicago with his pregnant wife Isabella, is linked to a violent terrorist organization by telephone records indicating that the terrorist who carried out the suicide attack placed several calls to Anwar's mobile phone. Returning to the United States from South Africa, he is incarcerated by American officials and sent to a secret detention facility, 
where he is interrogated and tortured. Isabella is not informed and all records of his being on the flight from South Africa are deleted. Freeman is assigned to observe the interrogation of Anwar, whose interrogator is Fawal himself. After Freeman briefly questions Anwar, he is doubtful of Anwar's guilt, but his boss, Corrine Whitman, insists that the detention continue, justifying such treatments as necessary to save thousands from becoming victims of terrorism. Growing worried, Isabella travels to Washington to see old friend, Alan Smith, who now works for a Senator and pleads with him to find out her husband's whereabouts. She is first told that Anwar had failed to board his plane, but Isabella shows him her husband's credit card statements, which shows that he made a purchase at the duty-free shop; this confirms that he was on the plane. Smith slowly connects the pieces together about the details of Anwar's detention. He is unable to convince either the senator or Corrine Whitman, who had ordered the rendition, to release him, or to openly acknowledge that the rendition was carried out. Upon hearing the confrontation from her office, his sympathetic secretary tips Isabella off that Whitman will be visiting the following day. She confronts Whitman and goes into labor in the hallway. Anwar eventually confesses that he advised terrorists how to make more powerful bombs and was promised 40,000 dollars in return. Suspicious that it's a false confession, Freeman asks where the money is and Anwar replies that it should have been delivered to him in South Africa but the courier never arrived. Without the consent of his superiors, Freeman approaches the a high level official of the country, and presents him with this finding, and also questions, whether the amount promised would really be enough to persuade a man whose annual salary is 200,000 dollars to risk his family. Eventually, Freeman persuades the minister to authorize Anwar's release and sends him back to America. Angered by the injustice Anwar has suffered, Freeman sends the details of Anwar's incarceration to the American press, creating a scandal that humiliates Whitman. The film ends with Anwar arriving home and reuniting with his family.

The most striking difference between Rendition and United 93 is its critical position towards the West and the War on Terror. The movie suggests that U.S. foreign policy played a significant part in the radicalization of Islam and that its extraordinary rendition and torture techniques are inhumane and abusive. Suspicious of everything related to the East or Islam, Corrine Whitman symbolically resides in a "white house." Dressed in white and situated in an almost sterile environment, she says "The United States does not torture". Yet the viewer at that point has already witnessed a torture scene. When the senator's aide Alan Smith confronts Whitman with El-Ibrahimi' s disappearance, she asks him what exactly is disturbing him: "The disappearance of a particular man or national security policy?" $\mathrm{He}$ concedes that "the hunt for and torture of terrorists is nasty business;" however, he justifies this by claiming that "there are over thousands of people alive tonight in London because of information we elicited just this way." Smith, however, is highly critical of infringement of the civil liberties of American citizens, and he sarcastically proposes to send a copy of the U.S. Constitution to her office to remind her that what the CIA is doing is deeply immoral and unconstitutional. Whitman justifies the potential sacrifice of one man's life for the lives of thousands of others. Unlike United 93, which confines Muslim characters to particular stereotypical images, Muslims in Rendition are round characters who experience a wide range of feelings that affect their decisions and acts.

After September 11 attacks the CIA initiated a program of "extraordinary rendition" to interrogate terrorism suspects. The CIA wanted to detain and interrogate foreign suspects without bringing them to the United States or charging them with any crimes. The torture scenes and Whitman's character put the U.S. government and the CIA in a very critical position. Describing Rendition as a movie "that puts a face to the practice of torture," Robert Ebert claims that the movie shows "that we, Americans, have 
lost faith in due process and the rule of law, and have forfeited the moral high ground" (Ebert, 2007: 3). The movie suggests that the U.S. government will do anything to track down possible terrorists and justifies the sacrifice of one man by claiming that it possibly saves other innocent lives.

The torture scene takes place in a dark and frightening atmosphere, with sounds of the rattling of chains and noises prisoners make while being tortured. Fawal, head of the secret police, carries out the torture, explaining to Freeman that their "work is crucial" since they "save lives". This political discourse is an evasion of responsibility. Because, an innocent life cannot be sacrifed for the greater good. Therefore, killing of innocent civilians cannot be condoned in any civilized society In the first torture scene, ElIbrahimi is screaming and begging while Fawal and his colleagues stand calmly in their suits carrying out the torture. Both are Muslims which relay the bitter message that Muslims are all the same and violent in nature. Even though, the movie supposedly refutes orientalist discourses, there are still traces of it throughout the movie. This frightening setting and the explicit images of torture emphasize how cruel and inhumane the practices could be. The scenes indicate that even though the torture does not take place in the U.S., it is still the U.S. that is fully responsible. In addition, the U.S. is complicit in radicalizing Islamic youth in Muslim countries, as becomes clear in the second story line. Initially, Fawal is portrayed critically as a traditional, authoritarian Muslim, who mistreats other Muslims and the women in his family. Gradually, however, Fawal appears to be a responsible father who is trying to protect his family. At the end of the movie, Fawal has lost his daughter in the suicide bombing, before the interrogation of El-Ibrahimi begins, but this information is deliberately withheld at this point in the movie. It is the suicide bombing of which he was the target that Fawal wants to solve. Fatima, Fawal's daughter, eloped with her boyfriend, Khalid. At the end, it is revealed that it is Khalid who carried out the suicide attack and attempted to kill Fawal. Fawal, as an accomplice, is responsible for the death of Khalid's brother. This loss causes him to radicalize and join a terrorist organization. This interesting twist in the plot shows that radicalization, torture, and terrorism are not simply results of Islam's ascetic teachings but also of personal reasons. Fawal is torturing El-Ibrahimi in a desperate attempt to find his daughter and Khalid is actually avenging his brother--both acting out of personal reasons. The bombing scene at the end of movie shows Khalid and Fatima standing at the square, where Fatima begs him not to kill her father and Khalid is hesitant. Khalid is humanized and his character has developed, as the viewer knows his motives for cooperating in the terrorist attack, and his indecision is obvious. He is not a murderer, nor is Fatima or Fawal for that matter. The movie portrays these Muslim characters as relatively complex and humane individuals, enabling the viewer to sympathize and identify with them. Yet, Rendition does not try to manipulate the audience into glorifying all Muslims as honorable and good-hearted, but emphasizes their humanity and diversity.

The movie also complicates the stereotype of oppressed Muslim women. Fawal appears to be an authoritarian Muslim father, but his sister is a single and emancipated woman who does not follow injunction of her religion to wear a headscarf, and his daughter elopes with her lover. Even though Fawal' $\mathrm{s}$ wife wears a headscarf, she is not simply an oppressed woman either. She defends her daughter and confronts him, asking Fawal to "call her... for me," because things "are not the same as when we were young", implying that she realizes the world has changed, and thus going against the Orientalist stereotype of a fixed Muslim stereotype. However, despite all the anti-Orientalist features, the movie has an American hero; Freeman. Consistent with his highly symbolic name, when Freeman meets Fawal, he hands over the questions the CIA would like him to ask El-Ibrahimi. Fawal allows Freeman to watch; but he is not allowed to interfere in the interrogation. Throughout the interrogation Freeman indeed acts indifferent. However, he seems uncomfortable with the situation, indicating that he disagrees with torturing a man without due process of law or a proof of his guilt. During the next torture scene, Freeman 
says "it is not working' and asks for a moment with El-Ibrahimi alone. During the ten minutes that are given to him, Freeman too resorts to violence. When El-Ibrahimi still does not admit to having ties with terrorists, Freeman's belief in his innocence is strengthened. It is not until El-Ibrahimi gives a false confession that Freeman's suspicions are confirmed entirely. True to his name, Freeman is the only person who is not satisfied with El-Ibrahimi' s confession and keeps digging, indicating his sense of justice and independent mind. He quotes Shakespeare while making a point on the value of intelligence gathered through torture: "I fear you speak upon the rack, Where men enforced do speak anything." He questions how often "truly legitimate intelligence" can be obtained through torture, implies that people who are tortured will eventually say anything to make the torture end. Moreover, Freeman acknowledges that if "you torture one person, you create ten, a hundred, a thousand new enemies." Freeman then risks his job to release El-Ibrahimi. As such, Freeman represents the "good" American, with a conscience and the will to find out the truth. In the end, the movie conveys the message that torture and extraordinary rendition is immoral and unconstitutional, for it does not save lives, but only contributes to the creation of more enemies. The movie shows significant amounts of violence, aggression, and terrorism as consequences of the September 11 attacks, yet these violent acts are not directed at Americans but surprisingly, at innocent Muslims, indicating that Muslims are victims of September 11 and terrorism as well.

The Muslim characters vary in their behavior and personality, which counters Orientalist portrayals. Fawal's character gradually develops throughout the movie and has some depth, and Khalid, the suicide bomber, radicalizes because of the U.S.- supported torture practices. The movie explores the motives and background stories of so-called "Other." It is critical of the U.S. government, suggesting that American leaders and security officials are just as fanatic as Islamic fundamentalists and will show no mercy. The movie ultimately complicates Orientalist discourses by featuring individual, in some cases well-rounded, Muslim characters and adopting a critical perspective on U.S. foreign policy and War on Terror practices.

Movies have provided one of the most effective sites for reflection on September 11. In order to respond to the conflicts between cultural and political entities, it proves to be a powerful tool. According to Steven Ross, movies "teach us how to think about race, gender, class, ethnicity, and politics" (Ross, 2014: 1). Since movies can have such a critical effect, popular movies could help to shape the ideas of their viewers. United 93 feeds the audience an image of the "Other" as violent and destructive, and simultaneously dangerous and vicious, suggesting through its quasi-documentary movie techniques that its portrayal of the terrorists is accurate. Rendition, on the other hand, attempts to give a more balanced view, showing that only a few Muslims are terrorists and that the U.S. government is partially responsible for the radicalization of Islam.

United 93 portrays the Muslim characters as more aberrant, uncivilized, irrational, and violent than the passengers, which confirms to the idea of a revival of Orientalism in the post- September 11 world, whereas in Rendition the diverse Muslim characters are portrayed empathetically as humans with commonplace problems and identifiable worries. United 93 emphasizes the cruelty of the attacks and, especially, the heroism of the American citizens who were faced with the challenge to overpower the armed terrorists. However, by convincing the viewers this as it is the true story, it suggests that its portrayal of the terrorists is real as well, although there is no way of verifying this claim. The terrorists' background and motives are kept in the dark, which tends towards an Orientalist portrayal of the "Other" who is completely different and threatening. The movie reproduces American exceptionalism through presenting the passengers as heroes fighting for their freedoms against the cruel "Other." In 
Rendition, however, the Muslim characters are portrayed as individuals and not all as religious fanatics. It invites the Western audience to look at the possibility that the U.S. might be complicit in the creation of terrorists, and that Muslims in other countries are also victims of terrorism. The idea that September 11 traumatized and affected only American citizens is undermined, for the movie mainly focuses on the suffering of Muslims in genral. Moreover, traditional Orientalist thinking is deconstructed in this movie, indicating that one cannot rigidly categorize people based on their religion, race, or descent. Rothberg launched the idea of "deterritorialized" (Rothberg, 2009: 71) America, which he thinks is centripetal and should instead be a centrifugal one (Rothberg, 2009: 153). In response, Gray introduced a model based on America becoming a universal nation, whereas Rothberg believes in the outward universalization of America. Rendition partially follows Gray's universal model but then switches towards Rothberg's model to show the outward movement and impact of "America's global reach" to reveal "the cracks in its necessarily incomplete hegemony” (Rothberg 158).

\section{Conclusion}

The ideological and political conflict between the West and the Muslim world is one of the most significant phenomena in the post- September 11 world further mediated and circulated by the Hollywood movies. Since Orientalist discourses and discrimination against Muslims are virulent in the post- September 11 world, most Westerners express anger and frustration towards Muslims and see terrorism and violence as inherent in Islam. Said's theory of Orientalism is, therefore, more relevant and popular than ever. Some scholars have objected to Said's theory and the problem of the reproduction of binary thinking therein. Said accuses Western scholars of being prejudiced about the East, and particularly Muslims. However, by categorizing the world into the West and East as well, and claiming that all Western scholars and Westerners in general are Orientalists, Said to a certain extent stereotypes Westerners himself. However, the prejudiced attitudes of many Westerners towards Muslims cannot be denied. Orientalist discourse of usual litany of grievances about the Islam; failure to separate religion from politics, incompatibility of democracy and Islam, hurt pride over a lost civilization, rejection of modernity, nostalgia for the past, and fascination with terrorism, the conflict between Islam and the West has been in the making for centuries. Circumstances in Muslim countries are volatile, yet to simply regard Islam as the embodiment of evil is to ignore other contributing factors, such as U.S. foreign policies, War on Terror practices and geopolitics.

My analysis of the movies United 93 and Rendition shows that United 93 reinforces and perpetuates conflicts by employing an orientalist discourse while Rendition counters the same discourse by employing a more balanced approach. Even though United 93 predominantly takes a Western paradigm and focuses on the experiences and traumas of the American citizens who were the victims in the attacks, it fails to avoid Orientalist Discourses. Rendition, on the other hand, places the attacks in an international context, featuring characters that deconstruct stereotypical and Orientalist representations of Muslims. The work criticizes U.S. foreign policy, the Patriot Act and the War on Terror, and finally shows that the U.S. is not the only victim of the September 11 attacks.

\section{Bibliography}

Ahmad, Leila. (2008). Women and Gender in Islam: Historical Roots of a Modern Debate. New Haven: Yale University Press. Boston. Print.

Ashcroft, Bill, Gareth Griffiths, and Helen Tiffin. (2002) The Empire Writes Back: Theory and Practice in Post-colonial Literatures. New York: Routledge, 2002. Print. 
Butler, Judith. (2001)“Giving an Account of Oneself.” Diacritics 31.4: 22-40.

Clifford, James. (1980). Review Orientalism by Edward Said. History and Theory 19.2 204-23.

Ebert, Roger. “Rendition.” 18 October 2007. Accessed March 30 2015. Web.

Ford, Elisabeth.(2001). "Hollywood's Take On September 11.” In Horror After September 11; World of Fear, Cinema and Terror. Ed. Aviva Briefel and Sam J. Miller. University of Texas Press.

Grewal, Inderpal. (2003) “Transnational America: Race, Gender and Citizenship after September 11.” Social Identities: Journal for the Study of Race, Nation and Culture: 9.4 535-561.

Gray, Richard. (2001) J. After the Fall: American Literature since September 11. Chichester, West Sussex: Wiley,.

Kumar, Malreddy Pavan. (2004)."Introduction: Orientalism(s) after September 11.” Journal of Postcolonial Writing: 33-40.

Khalid, Maryam. (2011). “Gender, Orientalism and Representations of the 'Other' in the War on Terror." Global Change, Peace \& Security 23.1: 15-29.

Lebling, Bob. (1980). “Orientalists.” Review Orientalism by Edward Said. Journal of Palestine Studies: 118-122.

Rendition. Dir. Gavin Hood. New Line Cinema: 2007.

Rothberg, Michael. (2009). "A Failure of the Imagination: Diagnosing the Post- September 11 Novel, A Response to Richard Gray.” American Literary History 21.1 : 152- 158.

Rickli, Christina. (2009). “An Event 'Like a Movie'? Hollywood and September 11.” COPAS: Current Objectives of Postgraduate American Studies 10.

Ross, Stevens. (2014). Movies and American Society. Chichester: John Wiley and Sons.

Said, Edward W. (1981). Covering Islam. London: Vintage.

Said, Edward W. (2014). Orientalism. London: Penguin.

United 93. Dir. Paul Greengrass. Universal Studios: 2006.

Zizek, Slavoj.(2006). "On September 11, New Yorkers Faced the Fire in the Minds of Men." The Guardian September 11. 